\title{
The Incumbency Bonus Revisited: Causes and Consequences of Media Dominance
}

\author{
CHRISTOFFER GREEN-PEDERSEN, PETER B. MORTENSEN AND \\ GUNNAR THESEN*
}

The literature on political actors' media appearances has repeatedly documented the so-called incumbency bonus (that parties and politicians in government have more media coverage than those in the opposition). This bias is normally attributed to news criteria that reflect political power, such as relevance and the elite status of actors. Supplementing existing perspectives, this study puts forward a new explanation of the incumbency bonus. The article argues that variations in the media dominance of incumbents are the result of the interplay between journalistic norms and political context. Outside election campaigns, political news is driven by the 'watch dog' norm. Thus the media focus on societal problems, which produces a critical emphasis on incumbent actors. But when party competition intensifies, either during campaigns or when issues become salient, the norm of objective and impartial journalism results in a more balanced coverage where challengers increase their presence. The argument receives support through multivariate models of incumbent and challenger appearances in Danish radio news broadcasts over a twenty-year period. Finally, in terms of democratic implications, the importance of the watchdog norm challenges the assumption that the incumbency bonus constitutes an electoral asset. Since media dominance is closely related to government responsibility for all kinds of problems, incumbent support is found to dwindle with increased media appearances.

Getting in the news is a central concern for politicians, and studying which politicians are prominent in the media has become an important task for the study of democratic politics. A central finding in this literature is the so-called incumbency bonus: the incumbent party or government leader gets more media coverage than the opposition or opposition leader. ${ }^{1}$ This finding potentially indicates that modern mass media reinforce formal political power by paying disproportionate attention to those who hold office. However, to assess the democratic implications of the incumbency bonus, we need to know more about its causes and consequences.

The existing literature typically explains incumbents' dominance in the news by referring to the importance of news values such as elite status and prominence. ${ }^{2}$ This 'reflection of power' explanation seems a plausible account of why incumbents generally appear in the news more often than their challengers. Yet this explanation reduces political journalism to merely reproducing the political power structure, thereby discounting the role of journalistic norms

* POLIS-Research Unit, Department of Political Science and Government, Aarhus University (emails: cgp@ps.au.dk, Peter@ps.au.dk, gunnar.thesen@iris.no; website: http://ps.au.dk/polis). Earlier versions of this article were presented at the 2013 meeting of the CES in Amsterdam, the ECPR 2013 General Conference in Bordeaux and the 2013 Annual Meeting of the Danish Political Science Association in Vejle. Thanks to our discussants and other attendants for their very helpful feedback. Also thanks to Stefaan Walgrave and Rune Slothuus for their constructive criticism. Online appendices and data replication sets are available at http://dx.doi. org/doi:10.1017/S0007123415000022

1 Asp 2006; Brants and van Praag 2006; de Swert 2011; Hopmann, de Vreese, and Albaek 2011; Schoenbach, de Ridder, and Lauf 2001; Schulz and Zeh 2006; Semetko 1996; van Aelst and de Swert 2009; van Dalen 2011.

${ }^{2}$ E.g., Hopmann, de Vreese, and Albaek 2011; Schoenbach, Ridder, and Lauf 2001; van Dalen 2011. 
such as political balance ${ }^{3}$ and the 'watchdog role of the media'. ${ }^{4}$ Furthermore, it does not sufficiently address the fact that the size of the bonus varies considerably.

To improve our understanding of the incumbency bonus, this article develops and tests an explanation of how journalists weigh partly conflicting norms against each other when covering political actors. This explanation not only accounts for the incumbency bonus but also allows us to predict variation within it. The point of departure is that the functioning of modern journalism is based on two important norms. The first norm is that modern media should serve as a 'watchdog' by focusing on societal problems and what should be done about them. ${ }^{5}$ This norm produces an emphasis on incumbent actors, as they hold policy responsibility. The other norm is that of objective and impartial journalism, ${ }^{6}$ which implies that both sides of a political conflict should receive attention.

The relative importance of these norms depends on the political context. For instance, the context of elections is expected to decrease the incumbency bonus. During election campaigns, the key question is who will win, thus a balanced coverage of the electoral contest implies attention to both incumbents and challengers. Between elections, the media are more focused on detecting and attributing responsibility for societal problems, which makes critical coverage of incumbents a dominant feature of political news. Similarly, the political context changes depending on the level of attention a given issue receives. Typically, increases in issue attention are accompanied by intensified political conflicts. When this happens, opposition parties become more newsworthy, and the incumbency bonus declines.

The implications of the theoretical argument are examined in a large- $\mathrm{N}$ analysis of media coverage of Danish politics over a twenty-year period (1984-2003). The dataset contains more than 30,000 daily radio news features, each of which has been coded according to the policy issue addressed (health, environment, etc.) and whether it includes a statement from a political actor. The dataset is unique in terms of the long time period covered with daily observations.

Furthermore, Denmark is a typical example of Hallin and Mancini's democratic corporatist media system with a central role of public broadcasting. ${ }^{7}$ Studying public broadcasting in the context of a democratic corporatist media system thus makes the findings generalizable to at least central and northern Europe. In addition, while most previous studies of the incumbency bonus have been based on election campaigns, ${ }^{8}$ we systematically compare the media coverage of political actors during and between election campaigns.

Our theorizing about the causes of the incumbency bonus challenges implicit perceptions of its consequences. Rather than assuming that media dominance reflects and reinforces political power, we stress that incumbents' media prominence is inextricably linked to bad news and the burden of being held responsible for all kinds of societal problems. To validate this claim, we supplement the media prominence code with a content coding of a subsample of the radio news in order to investigate the tone of the news (good, neutral, bad) and the presence of blame attributions directed at the government.

According to the above argument, media coverage is an important liability of policy responsibility. Consequently, the more that incumbents appear in the media, the worse they should perform in opinion polls. To examine this claim empirically, we conclude the analysis with a Granger causality-inspired analysis of the relationship between media prominence and

${ }^{3}$ Hopmann, van Aelst, and Legnante 2012.

${ }^{4}$ Bennett 2003; Zaller 2003.

5 Bennett 2003; Boydstun 2013, 58-77; Zaller 2003.

${ }^{6}$ Hopmann, van Aelst, and Legnante 2012.

${ }^{7}$ Hallin and Mancini 2004, 143-97.

${ }^{8}$ For an exception, see van Aelst and de Swert 2009. 
standing in opinion polls. Consistent with our argument, we find that for government parties, more media prominence is in fact followed by lower opinion ratings, whereas media prominence does not hurt the electoral support of the opposition.

\section{THE INCUMBENCY BONUS AND THE 'REFLECTION OF POWER ARGUMENT'}

Existing research on the media prominence of politicians in a number of different national contexts has shown that government parties/prime ministers experience more media coverage than the opposition and its leaders. ${ }^{9}$ The dominant explanation of this incumbency bonus draws on news value theory. A set of values exists among journalists, which specifies several properties of an event that increase its 'newsworthiness'. ${ }^{10}$ The presence of conflict is one such value. Other values are relevance and elite status, which make the news media focus on formal political power. Incumbents' decisions can affect nearly all aspects of society, which increases their relevance as objects of news coverage. This 'reflection of power' argument has not only been used to explain the incumbency bonus. ${ }^{11}$ It has also been applied to show that the news coverage of Members of Parliament (MPs) is "power dependent ${ }^{12}$ and to explain variation in media coverage of MPs across five countries. ${ }^{13}$

While the reflection of power argument provides a plausible explanation of the incumbency bonus, it also presents a rather broad and vague perspective on which political actors are prominent in the news, a perspective that portrays the media somewhat passively. Can journalism simply be reduced to reproducing the political power structure, and how does this fit with the norm of objectivity and political balance ${ }^{14}$ or the 'watchdog role of the media?' Furthermore, this explanation does not account for variation in the size of the incumbency bonus. Schoenbach, for instance, only finds an incumbency bonus in Germany and not in the Netherlands, ${ }^{15}$ and van Dalen points to cross-national variation depending on power relations in the political system and journalistic culture. ${ }^{16}$ Furthermore, van Aelst and de Swert find a lower incumbency bonus during elections than in 'normal' times. ${ }^{17}$ Thus the application of news value theory in the literature needs to be supplemented by a more explicit explanation of how journalists, in different political contexts, weigh partly conflicting norms against each other. The next section sketches the building blocks of such a theoretical contribution.

\section{The Role of Journalistic Norms and Political Context}

As argued by both Wolfsfeld and Boydstun, analyzing the production of political news requires theories that take into account the interaction between the political context and the functioning of the modern mass media. ${ }^{18} \mathrm{~A}$ first step is to recognize that professional journalistic norms may

9 Asp 2006; Brants and van Praag 2006; de Swert 2011; Hopmann, de Vreese, and Albaek 2011; Schoenbach, de Ridder, and Lauf 2001; Schulz and Zeh 2006; Semetko 1996; van Aelst and de Swert 2009; van Dalen 2011.

${ }^{10}$ Harcup and O'Neil 2001; Shoemaker 2006.

11 E.g., de Swert and Walgrave 2002; Hopmann, de Vreese, and Albaek 2011; Schoenbach, de Ridder, and Lauf 2001; van Dalen 2011.

12 Tresch 2009.

13 van Aelst, Shehata, and van Dalen 2010.

14 Hopmann, van Aelst, and Legnante 2012.

15 Schoenbach 2001.

16 van Dalen 2011.

17 van Aelst and de Swert 2009.

18 Boydstun 2013, 23-45; Wolfsfeld 1997, 2-5. 
sometimes contradict each other when it comes to coverage of political actors. The Western tradition of neutral informational journalism ${ }^{19}$ includes the concept of the media as watchdog. ${ }^{20}$ Empirical studies indicate that such a norm affects news coverage; they find, for instance, that the media have a clear negativity bias and focus disproportionately on societal problems or failures. ${ }^{21}$ In this context, the news value of elite status clearly implies responsibility, as political actors are considered important to the extent that they can be blamed for societal problems. Hence, the watchdog norm makes actors in office more newsworthy, but at the same time the media actively challenge (and not only reflect) political power.

Another central norm is political balance. Modern news media should present a 'neutral' and balanced picture of reality, and avoid political biases that could question the media's independence from political power. Exactly what political balance implies is debated. ${ }^{22}$ However, one clear implication is that the media should cover opposition as well as the government, as the relevance of political actors is gauged from the perspective of political conflicts more than from the perspective of societal problems.

The next step, then, is to consider how different aspects of political context affect the application of the two norms, thereby influencing who appears in the news. Our point of departure is that the watchdog norm, together with news values that encourage the 'reflection of power', generate a focus on the incumbent in media coverage of political actors. Political news is dominated by societal problems, and the news comes to both reflect and challenge political power when covering these problems. The expected outcome in terms of media prominence is spelled out in our baseline hypothesis:

HYPOTHESIS 1: Incumbents get more media coverage than the opposition.

This hypothesis is perfectly in line with the results of the existing literature. However, we are looking to expand this finding by explaining variation in incumbents' media prominence. First, we look at the difference between non-election and election times. Outside election campaigns, the political dynamic centers on the many societal problems that surface in news coverage. The opposition will often use news stories about societal problems to attack the government. Since it is not in office, the opposition can react to the news stories that it finds particularly attractive, for instance, news that directly questions government competence or attracts a great deal of attention. ${ }^{23}$ Governments find themselves in a much less flexible situation. When the media or political opponents raise questions about societal problems, the government has to respond, whether or not it actually has a chance to do something about the problems.

During election campaigns, the political contexts change. Part of a campaign is of course about how the government has performed, which still leads to an incumbency focus. However, electoral campaigns also revolve around what the future government will do, as incumbents and challengers debate which issues need to be addressed and which solutions need to be applied. This means the media will focus on the different contenders' platforms and ideas. ${ }^{24}$ Furthermore, elections are contests, during which the norm of objectivity demands more balance between the media visibility of incumbents and challengers. Overall, during campaigns, political actors are considered in the context of their role in party competition and less in light

${ }^{19}$ Hallin and Mancini 2004.

${ }^{20}$ Bennett 2003; Boydstun 2013, 58-77; Zaller 2003.

${ }^{21}$ Soroka 2012.

${ }^{22}$ Hopmann, van Aelst, and Legnante 2012.

23 Green-Pedersen and Mortensen 2010; Seeberg 2013; Thesen 2013.

${ }^{24}$ Cf. van Aelst and de Swert 2009. 
of policy responsibility. The implication of this argument is summarized in the following hypothesis:

HYPOTHESIS 2: The incumbency bonus is lower in election times than in non-election times.

Pushing this argument further, the nature and level of conflict between government and opposition not only differs between election and non-election times. Between elections, different policy issues attract varying amounts of political attention. As argued above, the incumbency bonus is partly the result of the opposition's greater flexibility, since it can choose not to react to news stories if it finds no advantage in doing so. ${ }^{25}$ Yet incumbents are obliged to respond, as they hold policy responsibility regardless of issue saliency. By contrast, when attention to an issue is high in the media, opposition parties have an incentive to join the media debate; otherwise they are unable to communicate their engagement in (and positions on) salient issues.

For journalists, issues that deal with government actors will be considered newsworthy even when they lack the conflict between political competitors that could sustain further coverage. However, when issues become politically salient, conflict and party competition supplement elite status and power as key news values. Consequently, the norm of balance increases its relevance in news coverage, in the same way it does during election campaigns. Overall, then, the size of the incumbency bonus is expected to vary with the degree of attention paid to issues in the media:

HYPOTHESIS 3: The incumbency bonus is greater when issues attract little media attention than when issues are subject to intensive media coverage.

The argument underlying a general incumbency bonus is that incumbents dominate media coverage due to their policy relevance. Therefore, the incumbency bonus should vary according to government strength. A majority government, which does not depend on the support of opposition parties to pass legislation, should produce the highest incumbency bonus. ${ }^{26}$ Minority governments that need to negotiate support with one or several opposition parties will, however, share a part of the incumbency bonus with the parties that support the government. This implies that the news picks up on the details of how policy responsibility is shared in a political system. Concentration of power makes it easier to identify and communicate who is responsible. ${ }^{27}$ The implication of these mechanisms is summarized in the following hypothesis:

HYPOTHESIS 4: Incumbents' media prominence increases with the government's parliamentary strength.

Finally, the argument on the causes of variation in the incumbency bonus has implications for its effect on electoral support. The existing literature has also paid attention to support in opinion polls, but from the opposite perspective. Hopmann, de Vreese and Albaek's study of Danish election campaigns found that the stronger the incumbent's standing in the polls, the higher the incumbency bonus. ${ }^{28}$ This is a logical consequence of mass media focus on who will form the next government.

Outside election campaigns, however, a reverse relationship should be expected. Most of the time, the next election is far away, making it unlikely that changes in poll standings have substantial effects on the balance in media coverage between incumbents and challengers.

\footnotetext{
25 Green-Pedersen and Stubager 2010; Thesen 2013.

26 Cf. van Dalen 2011.

27 Cf. Pierson 1994, 32-6.

28 Hopmann, de Vreese, and Albaek 2011.
} 
Instead, incumbent coverage is characterized by societal problems, negativity and blame, which, in the aggregate, will damage their electoral support. In other words, we question the assumption behind the concept of an incumbency 'bonus': that incumbents profit from a higher media prominence. Rather, if it is correct that incumbents' dominance in the media reflects the burden of being in government, then media prominence should be an electoral liability. This would also shed light on the well-documented but underexplored 'cost of ruling' finding in the voting literature, which holds that over time governments tend to lose electoral support. ${ }^{29}$ The implication of this argument is summarized in our final hypothesis:

HYPOTHESIS 5: Outside election campaigns, incumbent support in opinion polls decreases with increased media prominence.

\section{DATA AND RESEARCH DESIGN}

Investigating the hypotheses derived above is challenging. It requires a media dataset that covers several electoral cycles, a broad range of policy issues, and both strong and weak governments. Further, to assess the causal relationship between media prominence and electoral support, we not only need a long time series, but also observations with a high frequency. As argued in the following, a database on the Danish radio news in the period 1984-2003 meets these requirements quite closely.

The radio news was produced by the Danish Broadcasting Corporation, which enjoyed a de facto monopoly on broadcasting radio news nationally in this period. Studies of the Danish media system indicate that many stories originated in the major national newspapers, but that the hourly radio news was the most important filter for stories raised in the newspapers to make it onto the TV news in the evening. Radio news thereby constitutes the best single source for measuring the agenda of the mass media in general in Denmark. ${ }^{30}$

All news features in the long versions of the radio news broadcast at noon and 6.30 PM were coded. The dataset, which contains more than 190,000 news features, provides a unique opportunity to study the media prominence of political actors over a long time period and in different political contexts. Van Dalen argues that Denmark should exhibit relatively weak government dominance because of its consensus-based political system and pragmatic journalistic culture. ${ }^{31}$ Thus the Danish case does not constitute a particularly likely case for identifying an incumbency bonus. Furthermore, the fact that Denmark is dominated by minority governments with different levels of parliamentary support makes it a well-suited case with which to examine how changes in government strength affect the incumbency bonus (Hypothesis 4). ${ }^{32}$

We coded the issue content and political actors of each news feature. The issue content coding was conducted using a modified version of the Danish policy agendas coding scheme (see www.agendasetting.dk). We reduced the scheme's fifty-nine topic codes to twenty-seven policy issues such as crime, traffic, health, education and defense. With respect to political actors in the media, we coded what Ferree et al. label actor standing, not just visibility. ${ }^{33}$

29 E.g., Paldam and Skott 1995.

${ }^{30}$ Probably because of the limited tradition for 'self-made' stories, the Danish radio news have never been subject to any regulation of their coverage during election times, such as requiring a certain balance in their coverage. They also have no reputation for having a particular political slant.

31 van Dalen 2011, 39.

32 van Dalen (2011) discusses the relative strength of government and parliament. In the Danish context, this distinction is similar to the one between government and opposition, see below.

33 Ferree et al. 2002, 86. 
Thus political actors were only coded when they expressed a statement or when their statements were presented (not when they were just mentioned or criticized). Furthermore, the data measures prominence - the number of appearances, not just whether an actor is present in the news. ${ }^{34}$ The coding also allowed us to include multiple actors, such as groups of parties jointly presenting a statement. ${ }^{35}$ To test our hypotheses, we need to focus only on the radio news features that deal with political news in Denmark. Consequently, we exclude the large number of news features (approximately 70,000) that reports political news from abroad with no direct relation to Danish politics. Since our argument applies to political news, we have proxied this by selecting only the news features about Denmark in which a political actor appeared. The final dataset then contains 31,003 news features.

\section{Measuring the Incumbency Bonus}

The first step in measuring the dependent variable, Incumbency Bonus, is to operationalize the notion of opposition and government in the context of the Danish multiparty system. Danish politics is organized around a bloc of left-wing and a bloc of right-wing parties. The left-wing bloc consists of the Social Democrats, the Socialist People's Party and more extreme left-wing parties. Typically, the Social Liberals have also supported the left-wing bloc, although in certain periods, it supported the right-wing bloc. The latter was the case, for instance, during the centerright government from 1982 to 1993. The right-wing bloc consists of the Liberals and the Conservatives and more radical right-wing parties. The two small center parties, the Centre Democrats and Christian People's Party, have also typically supported the right-wing bloc. The Danish tradition for minority governments implies that not all parties from a bloc actually take part in the government. However, all parties clearly belong to a bloc when it comes to forming a government, and even the center parties that have sometimes changed blocs always indicate before an election which bloc they will support. ${ }^{36}$

In the following, we mainly compare the media prominence of the incumbent parties with that of the parties that constitute the most likely alternative government. ${ }^{37}$ However, we also try out an alternative operationalization in which parties that support the government (the government's parliamentary basis) also count as incumbents, and in which the entire bloc of opposition parties is included in the comparison group. ${ }^{38}$ It should be noted that there is no strong separation between executive and legislative power in the Danish context. This implies that the government parties are mainly prominent in the media as ministers. MPs from the government parties are normally very loyal to the cabinet and hardly ever ask the ministers critical questions in parliament. Danish politics is a struggle between ministers and the opposition parties.

To determine the incumbency bonus, we first calculated the media prominence of both incumbent and opposition actors. ${ }^{39}$ If, for instance, the incumbents have a score of 75 per cent, this means that a

${ }^{34}$ Tresch 2009, 74-5.

${ }^{35}$ Other actors than parties (such as interest groups, experts and public organizations) were also coded, but these are not included in this study. Green-Pedersen and Stubager (2007) contains the details of the coding.

${ }^{36}$ Green-Pedersen and Thomsen 2005.

37 Which parties would have formed an alternative government is, of course, not completely certain. However, the parties have always made it clear in advance of an election whether they had ambitions to join a government or not. Thus in practice, this is rather straightforward to determine.

${ }^{38}$ Appendix 1 provides an overview of Danish governments and the categorization of the different Danish parties.

${ }^{39}$ A government actor can either be the government in general (for instance, 'the government proposes to do so and so'), a minister or an MP/MEP from the governing party. Most government actors that appear in the media (79 per cent) belong to the first two categories (see also below). 
TA B LE 1 The Incumbency Bonus across Governments, 1984-2003

\begin{tabular}{lcccr}
\hline \hline Government & \multirow{2}{*}{ From } & Incumbency bonus & Alternative operationalization & $\mathrm{N}$ \\
\hline Schlüter I & $01.01 .1984(10.09 .1982)$ & 41.3 & 42.7 & 6,454 \\
Schlüter II & 10.09 .1987 & 36.3 & 37.0 & 1,315 \\
Schlüter III & 03.06 .1988 & 45.9 & 47.7 & 4,232 \\
Schlüter IV & 18.12 .1990 & 34.6 & 41.3 & 3,662 \\
Nyrup I & 25.01 .1993 & 52.3 & 55.1 & 2,968 \\
Nyrup II & 27.09 .1994 & 53.1 & 55.9 & 3,384 \\
Nyrup III & 30.12 .1996 & 46.6 & 54.2 & 1,838 \\
Nyrup IV & 23.03 .1998 & 44.9 & 52.6 & 4,631 \\
Fogh I & 27.11 .2001 & 47.4 & 47.3 & 2,519 \\
Total & 44.6 & 48.1 & 31,003 \\
\hline \hline
\end{tabular}

Note: Incumbency bonus is measured as the difference between the media prominence of governing parties and the alternative government. The alternative operationalization measures the bonus as the difference between the media prominence of the governing bloc (governing and support parties) and that of the opposition bloc (alternative government and alternative government support parties).

minimum of one government actor is present in three out of four news features on a given issue topic in a given week. The incumbency bonus was then calculated by simply subtracting the media prominence of opposition actors from the prominence of government actors.

Table 1 provides an overview of the incumbency bonus for each Danish government in the period. In line with Hypothesis 1, the table documents a clear media dominance for incumbent actors in all cabinets. However, it also provides support for the general contention of this article: that the size of the bonus varies. Note that the two different measures of the incumbency bonus produce very similar results. In the rest of the article, we use the first operationalization, which compares the parties in government with the government alternative, as this is the most conventional definition of incumbency.

\section{Modeling Approach and Measures of Explanatory Variables}

The ambition to explain variation in incumbents' media prominence implies that we need a multivariate test in which the effects of all explanatory variables are modeled simultaneously. Since our dataset includes several layers (issues and weeks) that may be considered groups or clusters of data, we estimate a set of multilevel models. More particularly, the multilevel analysis models the media prominence of both incumbent and opposition parties, observed per week per issue. We measure the media prominence of incumbent and opposition parties separately because it makes it possible to get a more detailed examination of changes in the incumbency bonus. This way we can separate out, for instance, whether a drop in the incumbency bonus indicates that the incumbent receives less attention, that the opposition receives more attention or both. Given our twenty-seven policy issues, this means that the dataset consists of twenty-seven categories repeated over 1,059 weeks for both incumbents and challengers $(27 \times 1,059 \times 2=57,186)$. As explained earlier, however, we only estimate relationships for the units (weeks $\times$ issue categories) in which a minimum of one political actor appears in the news. Thus the number of relevant cases is reduced to $25,274 .^{40}$

\footnotetext{
40 We use Stata's xtmixed command to run non-nested multilevel models, in which the variability at each level (issues and weeks) is estimated. The structure of the dataset is thus accounted for in the models, which estimate both fixed-effects parameters (coefficients) and random-effects parameters for crossed panels. The use of a
} 
TABLE 2 Descriptives of Variables in the Empirical Models

\begin{tabular}{lcccr}
\hline \hline Variable & Mean & Std. dev. & Min & Max \\
\hline Media prominence & 46.25 & 43.33 & 0 & 100 \\
Incumbents & 0.5 & 0.50 & 0 & 1 \\
Election campaign & 0.02 & 0.14 & 0 & 1 \\
News saliency & 6.9 & 5.4 & 1 & 60 \\
Parliamentary strength & 37.9 & 5.0 & 30.8 & 50.9 \\
Poll standing & 36.3 & 4.3 & 23.2 & 46.0 \\
Right of center government & 0.57 & 0.50 & 0 & 1 \\
\hline \hline
\end{tabular}

Table 2 provides descriptive information of the variables in the statistical models. A dummy variable, Incumbents, distinguishes between government/incumbents (coded 1) and alternative government/challengers (coded 0). The variable Election Campaign simply denotes the number of weeks in the campaign (note that an election campaign in Denmark usually lasts about three weeks). News Saliency is operationalized as the count of news features for each unit, which means for each issue category per week. Parliamentary Strength is measured as the share of seats in parliament of the government and alternative government parties. To test Hypotheses 2, 3 and 4, the latter three variables are interacted with the incumbent dummy variable. To examine Hypothesis 5, we also include weekly measures of the Poll Standing of incumbent and challenger parties. ${ }^{41}$ Finally, government color (Right of Center Government) was included as a control variable.

\section{FINDINGS}

Table 3 presents the central tests of Hypotheses 1-4. The stepwise introduction of the interaction terms in Table 3 makes it possible to assess how sensitive the statistical estimates are to changes in model assumptions. Whereas it is no surprise that the constitutive terms change when interaction terms are added, ${ }^{42}$ the robustness of the interaction terms both with and without the other interaction terms imply that we can confidently direct our attention to the full model (Model 5) when evaluating the hypotheses.

Consistent with Hypothesis 1, which states that incumbents get more media coverage than the opposition, incumbency status has a strong and positive impact on political actors' share of media coverage. Furthermore, in line with Hypothesis 2, that the incumbency bonus will be greater in normal times than during election campaigns, Table 3 shows that the gap in media prominence between incumbents and challengers is reduced during election campaigns, as the negative and statistically significant coefficient for the interaction of Incumbents and Election Campaign indicates. Table 4 spells out this interaction effect, showing that while incumbents experience a small reduction in coverage during campaigns, challengers increase their prominence by 6 percentage points. In other words, the existence of an incumbency bonus is clearly not limited to election campaigns, which have been the focus of the existing literature. We find that incumbent actors' dominance of the news is more pronounced outside election campaigns.

non-nested model reflects that, logically, there is no nesting between weeks and issues (see also Rabe-Hesketh and Skrondal 2008, chapter 11).

41 Surveys were performed by Gallup and the data made available by Jacob Askham-Christensen (2012).

42 See Brambor, Clark, and Golder 2006. 
TA B LE $3 \quad$ Media Prominence of Incumbents and Challengers

\begin{tabular}{|c|c|c|c|c|c|c|}
\hline & Hypotheses & (1) & (2) & (3) & (4) & (5) \\
\hline Incumbents & (H1) & $\begin{array}{l}48.94 * * * \\
(0.61)\end{array}$ & $\begin{array}{l}49.07 * * * \\
(0.61)\end{array}$ & $\begin{array}{l}50.75 * * * \\
(0.84)\end{array}$ & $\begin{array}{l}27.52 * * * \\
(4.60)\end{array}$ & $\begin{array}{l}29.59 * * * \\
(4.64)\end{array}$ \\
\hline Election Campaign & & $\begin{array}{c}2.32 \\
(1.55)\end{array}$ & $\begin{array}{l}7.00 * * \\
(2.19)\end{array}$ & $\begin{array}{l}2.32 \\
(1.55)\end{array}$ & $\begin{array}{l}1.96 \\
(1.55)\end{array}$ & $\begin{array}{l}6.37 * * \\
(2.19)\end{array}$ \\
\hline News Saliency & & $\begin{array}{c}0.09+ \\
(0.05)\end{array}$ & $\begin{array}{c}0.09 \\
(0.05)\end{array}$ & $\begin{array}{l}0.22 * * * \\
(0.06)\end{array}$ & $\begin{array}{c}0.09 \\
(0.05)\end{array}$ & $\begin{array}{l}0.22 * * * \\
(0.06)\end{array}$ \\
\hline Parliamentary Strength & & $\begin{array}{l}0.18 * * \\
(0.06)\end{array}$ & $\begin{array}{l}0.19 * * \\
(0.06)\end{array}$ & $\begin{array}{l}0.18^{* *} \\
(0.06)\end{array}$ & $\begin{array}{c}-0.20 \\
(0.10)\end{array}$ & $\begin{array}{c}-0.19 \\
(0.10)\end{array}$ \\
\hline Right of Center Government & & $\begin{array}{c}0.27 \\
(0.48)\end{array}$ & $\begin{array}{l}0.30 \\
(0.48)\end{array}$ & $\begin{array}{c}0.26 \\
(0.48)\end{array}$ & $\begin{array}{c}0.19 \\
(0.48)\end{array}$ & $\begin{array}{c}0.21 \\
(0.48)\end{array}$ \\
\hline Incumbent $\times$ Election Campaign & $(\mathrm{H} 2)$ & & $\begin{array}{c}-9.34 * * \\
(3.10)\end{array}$ & & & $\begin{array}{c}-8.80 * * \\
(3.10)\end{array}$ \\
\hline Incumbent $\times$ Saliency & (H3) & & & $\begin{array}{c}-0.26^{* *} \\
(0.08)\end{array}$ & & $\begin{array}{c}-0.25^{* *} \\
(0.08)\end{array}$ \\
\hline Incumbent $\times$ Parliamentary Strength & (H4) & & & & $\begin{array}{l}0.58 * * * \\
(0.12)\end{array}$ & $\begin{array}{l}0.57 * * * \\
(0.12)\end{array}$ \\
\hline Constant & & $\begin{array}{l}14.39 * * * \\
(2.41)\end{array}$ & $\begin{array}{l}13.94 * * * \\
(2.42)\end{array}$ & $\begin{array}{l}13.56 * * * \\
(2.43)\end{array}$ & $\begin{array}{l}27.28 * * * \\
(3.66)\end{array}$ & $\begin{array}{l}25.95 * * * \\
(3.67)\end{array}$ \\
\hline Random-effects parameters & & & & & & \\
\hline Variance (issues) & & 3.17 & 3.17 & 3.17 & 3.16 & 3.16 \\
\hline Variance (weeks) & & 0.00 & 0.00 & 0.00 & 0.00 & 0.00 \\
\hline Residual deviation & & 35.17 & 35.17 & 35.17 & 35.16 & 35.15 \\
\hline$N$ & & 25,274 & 25,274 & 25,274 & 25,274 & 25,274 \\
\hline Wald $\chi^{2}$ & & $12,847.1^{* * *}$ & $12,860.3^{* * *}$ & $12,861.7 * * *$ & $12,879.8^{* * *}$ & $12,905.9^{* * *}$ \\
\hline Log restricted-likelihood & & $-125,859.8$ & $-125,853.2$ & $-125,856.4$ & $-125,850.0$ & $-125,840.5$ \\
\hline
\end{tabular}

Note: Standard errors in parentheses. ${ }^{*} p<0.05, * * p<0.01, * * * p<0.001$. Wald $\chi^{2}$ tests whether all covariates are jointly significant. 
TABLE 4 Predicted News Coverage of Incumbents and Challengers in Routine and Election Times (Hypothesis 2)

\begin{tabular}{lccc}
\hline \hline & Routine times & Election campaigns & Difference elections-routine times \\
\hline Incumbents & 70 & 68 & 2 \\
Challengers & 21 & 27 & -6 \\
Incumbency bonus & 49 & 41 & 8 \\
\hline \hline
\end{tabular}

Note: Estimated with Model 5, Table 3. The rest of the independent variables are set at their mean.

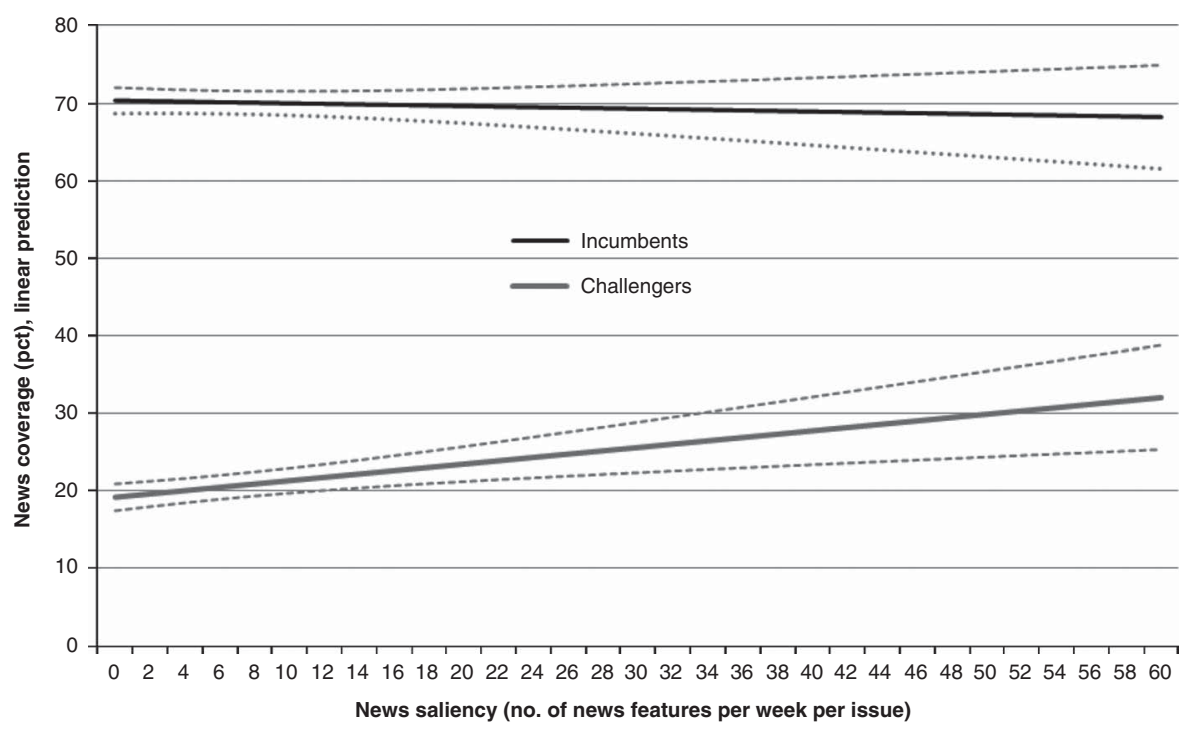

Fig. 1. Predicted news coverage of incumbents and challengers as news saliency changes (Hypothesis 3) Note: Estimated with Model 5, Table 3. The rest of the independent variables are set at their mean.

Hypothesis 3 - that the incumbency bonus decreases with increasing media attention - is also supported by the results presented in Table 3. News saliency has a negative and statistically significant effect on incumbency dominance in media coverage. This interaction effect between Incumbents and News Saliency is illustrated in Figure 1, which shows how the lines representing incumbents and challengers move closer as the number of broadcasted news features per week for an issue increases. Thus when an issue attracts a minimum of media attention, the incumbency bonus exceeds a 50-percentage-point difference. However, for the issues that receive maximum attention in a given week, this difference in media prominence is reduced by 15 percentage points. In other words, the more intensively the media focus on an issue, the weaker the incumbency bonus becomes.

According to Hypothesis 4, incumbents' media prominence is expected to increase with the parliamentary strength of the government. This expectation is supported by the positive and statistically significant interaction between Incumbents and Parliamentary Strength in Table 3. To illustrate the marginal effects of this interaction term, Figure 2 shows adjusted predictions of media prominence across the range of parliamentary strength that governments enjoyed in the period we study. The change from a weak minority government with a parliamentary base of 34 


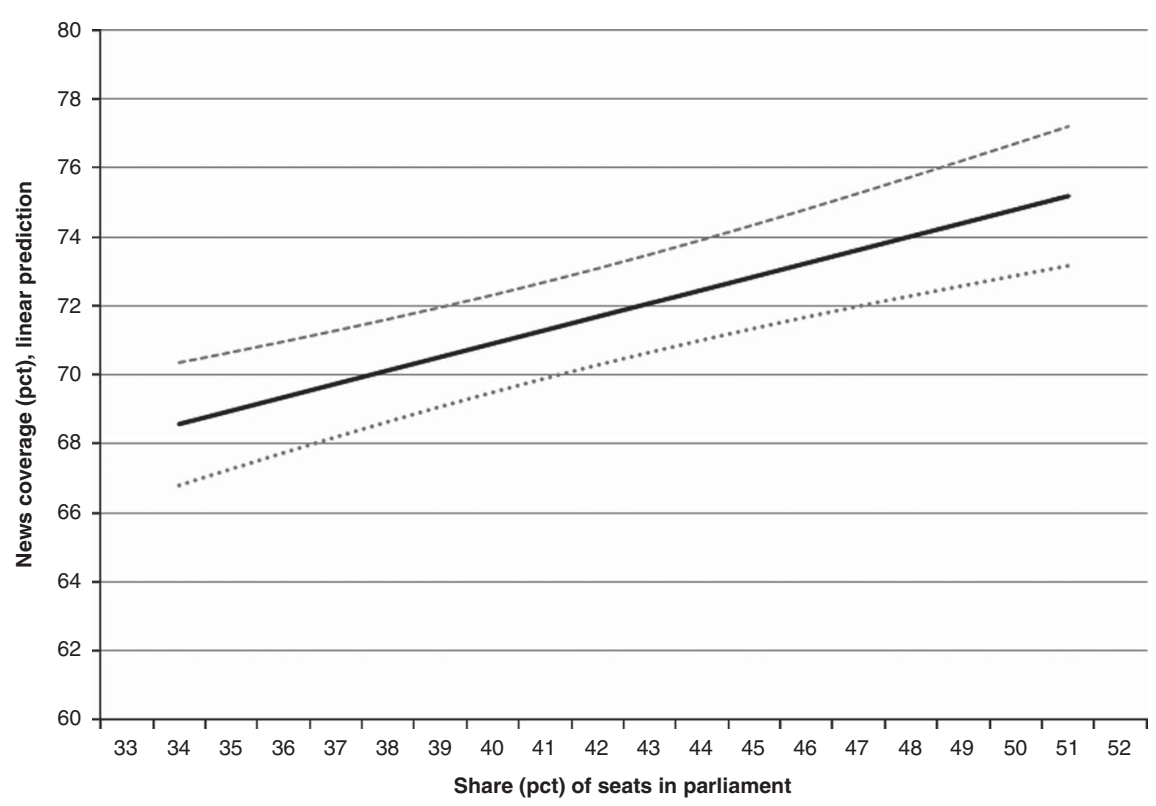

Fig. 2. Predicted news coverage of incumbents as parliamentary strength changes (Hypothesis 4) Note: Estimated with Model 5, Table 3. The rest of the independent variables are set at their mean.

per cent to a strong government controlling 51 per cent of parliament increases incumbent media coverage by nearly 7 percentage points.

\section{Media Prominence and Electoral Support}

As noted above, during election campaigns, the incumbency bonus has been shown to increase with increasing incumbent strength in opinion polls. ${ }^{43}$ However, as summarized in Hypothesis 5, our expectation is that outside election campaigns, incumbent support in opinion polls decreases with increases in media prominence. This expectation follows from the argument that outside election campaigns, the watchdog norm and the negativity bias of the media imply a strong focus on the government's responsibility for, and (lack of) responses to, societal problems and failures.

A first step in evaluating this idea is to document the negativity bias in the media and the critical coverage of government actors. To do this, we draw on a sample of radio news items from the year 2003, which have been further content coded. In addition to the measure of actor prominence used above, the sample includes a tone coding based on whether the news item is bad, neutral or good from the incumbent's point of view, as well as a coding of whether the government is explicitly criticized in the news. ${ }^{44}$

Based on this content coding, Table 5 clearly shows that considerably more news items are bad than good from the government's point of view (49 per cent vs. 22 per cent). This is even the case when government actors appear in the news, though the dominance of bad versus good news is less pronounced compared to when no government actor is present (50 per cent vs. 22 per cent, compared to 44 per cent vs. 24 per cent). Furthermore, Table 6 shows that in

43 Hopmann, de Vreese, and Alaek 2011.

44 This sample of radio news data was originally applied in Thesen (2013). 
TAвLE $5 \quad$ News Tone in Sample of Radio News Features from $2003(N=1,980)$

\begin{tabular}{lccr}
\hline \hline & News without government actors & News with government actors & Total \\
\hline News tone & & & \\
Bad & $50 \%$ & $44 \%$ & $49 \%$ \\
Neutral & $28 \%$ & $32 \%$ & $29 \%$ \\
Good & $22 \%$ & $24 \%$ & $22 \%$ \\
Total & $100 \%$ & $100 \%$ & $100 \%$ \\
& & & \\
\hline \hline
\end{tabular}

TABLE 6

Government Criticism in Sample of Negative Radio News Features from 2003 $(N=972)$

\begin{tabular}{lccr}
\hline \hline & News without government actors & News with government actors & Total \\
\hline Government criticism & & & \\
Without & $83 \%$ & $45 \%$ & $76 \%$ \\
With & $17 \%$ & $55 \%$ & $24 \%$ \\
Total & $100 \%$ & $100 \%$ & $100 \%$ \\
\hline \hline
\end{tabular}

55 per cent of the negative news features in which incumbents appear, the government is explicitly subject to blame and criticism. ${ }^{45}$ When government actors do not appear, the corresponding share of criticism is only 17 per cent. Thus incumbents' media prominence is clearly associated with more government criticism.

Having established that news is generally bad for the government, and that government actors in the news are associated with government criticism, the next step is to see whether government actors' prominence in the media is associated with declining government support in opinion polls (Hypothesis 5). To examine this question, we perform a set of Granger causality tests of the relationship between opinion polls and media prominence. As expressed by Granger, the logic of this approach is that: '[...] $Y_{t}$ is causing $X_{t}$ if we are better able to predict $X_{t}$ using all available information than if the information apart from $Y_{t}$ had been used' ${ }^{46}$

Including both one- and two-week lags in the model, Table 7 provides evidence of one-sided causality going from media prominence to standing in polls. Furthermore, the effect is negative, which supports the idea that media prominence may be a double-edged sword, but only for incumbent parties (see Model 1 in Table 7) and not for the opposition (see Model 3 in Table 7). In combination with the results of the more detailed coding shown in Tables 5 and 6, this Granger causality-inspired analysis challenges the idea that media dominance is a bonus, instead offering an integrated perspective of the causes and consequences of the incumbency bonus: If what gets a party in the news is a combination of policy responsibility and the media's critical coverage of societal problems, then media visibility is likely to come at the expense of electoral support. ${ }^{47}$

45 This coding does not capture how the opposition is covered, but in most instances, it would probably be justified to infer that what is bad for the government is good for the opposition, and that the coverage of the opposition is therefore more positive.

46 Granger 1969, 428.

47 The dataset contains too few election weeks to run the Granger-inspired analysis for election weeks separately. The models in Table 7 have been estimated without election weeks. If we re-run the analysis including election weeks, the negative effects of media coverage on incumbent party support are, as expected, slightly weaker. 
TA в 7 Granger Causality-Based Multilevel Models of the Relationship between Media Prominence and Poll Standing (Hypothesis 5)

\begin{tabular}{|c|c|c|c|c|}
\hline & (1) & (2) & (3) & (4) \\
\hline & Incumbent parties & Incumbent parties & Challenger parties & Challenger parties \\
\hline & \multicolumn{4}{|c|}{ Dependent variables } \\
\hline & Polls $_{\mathrm{t}}$ & Media prominence $_{t}$ & Polls $_{\mathrm{t}}$ & Media prominence $_{t}$ \\
\hline \multicolumn{5}{|l|}{ Independent variables } \\
\hline Media prominence $_{t-1}$ & $\begin{array}{c}-0.0003 * * \\
(0.0001)\end{array}$ & $\begin{array}{l}0.0376^{* *} \\
(0.0142)\end{array}$ & $\begin{array}{r}-0.0002 \\
(0.0001)\end{array}$ & $\begin{array}{l}0.0718 * * * \\
(0.0141)\end{array}$ \\
\hline Media prominence $_{t-2}$ & $\begin{array}{c}0.0002 \\
(0.0001)\end{array}$ & $\begin{array}{l}0.0381 * * \\
(0.0140)\end{array}$ & $\begin{array}{c}-0.0000 \\
(0.0001)\end{array}$ & $\begin{array}{c}0.0326^{*} \\
(0.0139)\end{array}$ \\
\hline Polls $_{t-1}$ & $\begin{array}{l}0.4537 * * * \\
(0.0119)\end{array}$ & $\begin{array}{c}0.5550 \\
(0.4668)\end{array}$ & $\begin{array}{l}0.5329 * * * \\
(0.0122)\end{array}$ & $\begin{array}{c}0.2448 \\
(0.6843)\end{array}$ \\
\hline Polls $_{\mathrm{t}-2}$ & $\begin{array}{l}0.3573 * * * \\
(0.0118)\end{array}$ & $\begin{array}{c}-0.4509 \\
(0.4645)\end{array}$ & $\begin{array}{l}0.4087 * * * \\
(0.0122)\end{array}$ & $\begin{array}{c}-0.5583 \\
(0.6812)\end{array}$ \\
\hline Constant & $\begin{array}{l}7.0276^{* * * *} \\
(0.3430)\end{array}$ & $\begin{array}{l}61.6197 * * * \\
(4.9808)\end{array}$ & $\begin{array}{l}2.0816^{* * * *} \\
(0.1902)\end{array}$ & $\begin{array}{l}31.3042 * * * \\
(3.9002)\end{array}$ \\
\hline \multicolumn{5}{|c|}{ Random-effects parameters } \\
\hline Variance (issues) & 0.000 & 8.924 & 0.000 & 4.853 \\
\hline Variance (weeks) & 1.296 & 2.283 & 0.701 & 0.002 \\
\hline Residual deviation & 0.375 & 34.242 & 0.257 & 31.588 \\
\hline$N$ & 6,962 & 5,118 & 6,962 & 5,118 \\
\hline$\chi^{2}$ & $9,963.47 * * *$ & $342.76 * * *$ & $9,509.92 * * *$ & $80.47 * * *$ \\
\hline
\end{tabular}

Note: Standard errors in parentheses $* p<0.05, * * p<0.01, * * * p<0.001$. 


\section{Robustness of Results}

We have explored the robustness of the main findings in several ways. First, we re-ran the analyses reported in Table 3 after replacing the measure of incumbents with a measure that only counts ministers as incumbents (excluding MPs and members of the European Parliament (EP) from governing parties). This shows essentially the same results as already reported. ${ }^{48}$

Secondly, we re-estimated the models presented in Table 3 by excluding the twenty-seven issues one at a time. This jackknife analysis provides information about the sensitivity of the conclusions to the impact of potential issue outliers. It turns out, however, that excluding issues had no important effect on the results reported above. We find an incumbency bonus (of varying strength) in all jackknife analyses.

Thirdly, as van Aelst and de Swert also include EP and local elections, we added these election weeks both separately and in combination with national elections. ${ }^{49}$ On their own, EP and local elections were not statistically significant and had no substantial effect on the other results. From this, we conclude that non-national elections are considered quite differently from a media perspective than national elections (results of all robustness checks are available upon request).

Finally, we utilize the opportunities that the Danish minority governments offer to test how sensitive the media coverage is to the political context. Recall that in systems with frequent minority governments, some of the media dominance that governments in majority systems enjoy could, potentially, rub off on opposition parties that support the government. Furthermore, support parties are interesting from a media perspective because they hold blackmail potential vis-à-vis the government. When a minority government proposes new policies, there is often considerable media interest in how support parties respond. This feature of minority rule adds a special dynamic of interest for the media: a potential conflict within the government bloc. In sum, the political context of minority rule means that some nongovernment parties are deemed more newsworthy than others because they exert more policy influence and hold more policy responsibility.

To investigate this difference, we ran the same analyses as those reported in table 3 above, replacing the variable Incumbents with an Incumbent Support dummy variable that separates government support parties (coded 1) from parties that support the government alternative (coded 0). The central result is that parties that support the government do have more news coverage than opposition parties that would have supported the alternative government - also when controlling for their parliamentary strength (results are not shown but are available from the authors upon request). We interpret this finding as further evidence of how political context variables matter when explaining the media prominence of political actors.

\section{CONCLUSION}

This article has suggested a new perspective on the media prominence of political parties. The goal was not just to show the existence of an incumbency bonus, but also to improve our understanding of why it varies and what its consequences might be. Supplementing the 'reflection of power' perspective that has dominated the literature so far, we argue that the interaction between political context and journalistic norms and news values determines the level of media prominence. Decisions about the newsworthiness of incumbents and challengers

\footnotetext{
48 The dataset also contains the length (in seconds) of radio-news features. Thus instead of just counting the number of radio features with a given actor, one could also look at how long the actors were present in the news. Running the models with this variable instead produced results almost identical to those reported in Table 3 (results are available upon request).

49 van Aelst and de Swert 2009.
} 
are not products of a fixed recipe, but change according to the political reality being covered. When the political context changes, the relative importance of the watchdog norm and the norm of political balance is affected. These different norms highlight that the news relevance of political actors is sometimes gauged from the perspective of societal problems and failures, where a critical focus on incumbents is highly relevant, and at other times from the perspective of political conflicts or party competition, implying that the issue of impartiality and balance between contenders is crucial. Therefore, we have argued that during election campaigns and conflicts over salient issues, the journalistic norm of political balance increases its importance at the expense of the critical watchdog norm, leading to a reduction in the incumbency bonus.

Thus the incumbency bonus is the result of how the media focus on societal problems and confront the government with problems it is expected to solve. What is interpreted as a question of government power in the existing literature is, from our perspective, just as much a question of responsibility: the media reflect and challenge political power by addressing the responsibility that accompanies it. In fact, considering the critical news attention underlying the dominance of government actors in the media, talking about an incumbency 'bonus' is questionable unless negative coverage is better than no coverage. However, it does not seem so. The Granger causality-inspired analysis above indicates that increases in the media coverage of incumbents tend to be followed by a drop in opinion polls.

Our findings draw on a dataset of Danish radio news from 1984-2003. The dataset is unique in terms of the length of the time period covered with data on a daily basis, whereas most of the existing findings are based on a single election campaign only. As mentioned, Denmark is a typical example of Hallin and Mancini's democratic corporatist model. ${ }^{50}$ One characteristic aspect of this model is the central role of public broadcasting, which further supports the relevance of using public radio news. Thus our findings should at least be generalizable to the northern and central European countries, which are relatively similar in terms of media systems. However, the ideas of neutral informative journalism cut across all media systems, just as the importance of public broadcasting can also be found in the UK, which otherwise has a more market-oriented media system. ${ }^{51}$ Thus the findings reported above most likely have relevance beyond the northern and central European context.

The above results illustrate how increased knowledge of the incumbency bonus affects our perception of its democratic implications. Existing research has shown how this phenomenon is a near-universal aspect of media-politics relations in Western democracies. However, the term 'bonus' suggests that this media bias mostly works in the favor of incumbents. This argument rests on the fact that politicians depend on the media to communicate with the electorate, and that media dominance therefore - in theory - could be translated into electoral support. Our perspective, stressing the watchdog norm and news negativity, has clearly challenged calling the effect a 'bonus'.

One possible further interpretation of our results is that modern mass media countervail political power, and that the incumbency bonus should be considered a positive, democratic phenomenon. ${ }^{52}$ However, as argued by Bennett, ${ }^{53}$ this is debatable. For instance, news values that favor simplicity, scandal and personalization might disturb the straightforward conclusion that incumbent dominance in the news contributes to democratic control. What if the watchdog

\footnotetext{
50 Allern and Blach-Ørsten 2011; Hallin and Mancini 2004, 143-97.

51 Hallin and Mancini 2004, 21-45.

52 Cf. Zaller 2003.

53 Bennett 2003
} 
norm is applied in a way that leads to media focus on small problems or non-policy related events at the expense of important and complex policy problems that are less newsworthy? Thus the question of which problems attract media attention becomes central, again pointing to the need for more research on the relationship between media prominence and democratic politics.

\section{REFERENCES}

Allern, Sigurd, and Mark Blach-Ørsten. 2011. The News Media as a Political Institution: A Scandinavian Perspective. Journalism Studies 12 (1):92-105.

Askham-Christensen, Jacob. 2012. The Logic of Political Competition and Government Responsiveness in Parliamentary Systems. Odense: University Press of Southern Denmark.

Asp, Kent. 2006. Rättvisa nyhetsmedier - Partiskheten under 2006 års medievalrörelse. (Accurate News Media, Party Balance in the News during the 2006 Campaign) JMG Arbetsrapport No. 42, Gothenburg University.

Bennett, W. Lance. 2003. The Burglar Alarm that Just Keeps Ringing. A Response to Zaller. Political Communication 20 (2):131-8.

Boydstun, Amber. 2013. Making the News: Politics, the Media, and Agenda Setting. Chicago, IL: University of Chicago Press.

Brambor, Thomas, Wiliam R. Clark, and Matt Golder. 2006. Understanding Interaction Models. Improving Empirical Analyses. Political Analysis 14 (1):63-82.

Brants, Kees, and Phillip van Praag. 2006. Signs of Media Logic: Half a Century of Political Communication in the Netherlands. Javnost - The Public 13 (1):25-40.

de Swert, Kurt. 2011. Where is the Balance in the News? PhD dissertation, University of Antwerp.

de Swert, Kurt, and Stefaan Walgrave. 2002. De kanseliersbonus in de Vlaamse pers: een onderzoek naar regering en oppositie in drie Vlaamse kranten (1991-2000) (The Incumbency Bonus in the Fleimish News. A Study of Government and Opposition in Three Flemish Newspapers). Tijdschrift Voor Sociologie 23 (3/4):371-403.

Ferree, Myra Max, William A. Gamson, Jürgen Gerhards, and Dieter Rucht. 2002. Shaping Abortion Discourse: Democracy and the Public Sphere in Germany and the United States. New York: Cambridge University Press.

Granger, Clive W. J. 1969. Investigating Causal Relations by Econometric Models and Cross-Spectral Methods. Econometrica 37 (3):424-38.

Green-Pedersen, Christoffer, and Lisbeth H. Thomsen. 2005. Bloc Politics vs. Broad Cooperation. The Functioning of Danish Minority Parliamentarism. The Journal of Legislative Studies 11 (2):153-69.

Green-Pedersen, Christoffer, and Peter B. Mortensen. 2010. Who Sets the Agenda and Who Responds to it in the Danish Parliament? European Journal of Political Research 49 (2):257-81.

Green-Pedersen, Christoffer, and Rune Stubager. 2007. Coding of Danish Radio News 1984-2003. Aarhus: Department of Political Science, Aarhus University. Available from www.agendasettting. dk, accessed 4 February 2015.

- 2010. The Political Conditionality of Mass Media Influence. When Do Parties Follow Mass Media Attention? British Journal of Political Science 40 (3):663-77.

Hallin, Daniel C., and Paolo Mancini. 2004. Comparing Media Systems: Three Models of Media and Politics. Cambridge: Cambridge University Press.

Harcup, Tom, and Deidre O'Neill. 2001. What is News? Galtung and Ruge Revisited. Journalism Studies 2 (2):261-80.

Hopmann, David, Claes de Vreese, and Erik Albaek. 2011. Incumbency Bonus in Election News Coverage Explained. Journal of Communication 61 (2):264-82.

Hopmann, David, Peter van Aelst, and Guido Legnante. 2012. Political Balance in the News. Journalism 13 (2):240-57.

Paldam, Martin, and Peter Skott. 1995. A Rational Voter Explanation for the Cost of Ruling. Public Choice 83:159-74. 
Pierson, Paul. 1994. Dismantling the Welfare State. Cambridge: Cambridge University Press.

Rabe-Hesketh, Sophia, and Anders Skrondal. 2008. Multilevel and Longitudinal Modeling Using Stata, 2nd Edition. College Station, TX: Stata Bookstore.

Schoenbach, Klaus, Jan de Ridder, and Edmund Lauf. 2001. Politicians on TV News: Getting Attention in Dutch and German Election Campaigns. European Journal of Political Research 39 (44):519-31.

Schulz, Winfried, and Reimar Zeh. 2006. Die Kampagne im Fernsehen - Agens und Indikator des Wandels. Ein Vergleich der Kandidatendarstellung. (The Television Campaign - Trigger and Indicator of Change. A Comparison of the Presentation of Candidates. In Die Massenmedien im Wahlkampf - Die Bundestagswahl 2005 (The Mass Media and the 2005 Campaign), edited by Christina Holtz-Bacha, 277-305. Wiesbaden, Germany: VS Verlag für Sozialwissenschaften.

Seeberg, Henrik. 2013. The Opposition's Policy Influence Through Issue Politicisation. Journal of Public Policy 33 (1):89-107.

Semetko, Holli. 1996. Political Balance on Television - Campaigns in the United States, Britain, and Germany. International Journal of Press/Politics 1 (1):51-71.

Shoemaker, Pamela. 2006. News and Newsworthiness: A Commentary. Communications 31 (1):105-11. Soroka, Stuart. 2012. The Gatekeeping Function: Distributions of Information in Media and the Real World. Journal of Politics 74 (2):514-28.

Thesen, Gunnar. 2013. When Good News is Scarce and Bad News is Good. European Journal of Political Research 52 (3):364-89.

Tresch, Anke. 2009. Politicians in the Media. Determinants of Legislators' Presence and Prominence in Swiss Newspapers. International Journal of Press/Politics 14 (1):67-90.

van Aelst, Peter, and Kurt de Swert. 2009. Politics in the News: Do Campaigns Matter? Communications 34 (1):149-68.

van Aelst, Peter, Adam Shehata, and Arjen van Dalen. 2010. Members of Parliament: Equal Competitors for Media Attention? Political Communication 27 (3):310-25.

van Dalen, Arjen. 2011. Structural Bias in Cross-National Perspective: How Political Systems and Journalism Cultures Influence Government Dominance in the News. International Journal of Press/ Politics 17 (1):32-55.

Wolfsfeld, Gadi. 1997. Media and Political Conflict. News from the Middle East. Cambridge: Cambridge University Press.

Zaller, John. 2003. A New Standard of News Quality: Burglar Alarm for the Monitorial Citizen. Political Communication 20 (1):109-30. 